\title{
Skin manifestation of mantle cell lymphoma - case report and literature review
}

\author{
Skórna manifestacja chłoniaka z komórek płaszcza - opis przypadku \\ i przegląd piśmiennictwa
}

\author{
Agnieszka Markiewicz', Natalia Zdanowska', Agnieszka B. Owczarczyk-Saczonek', Mateusz M. Markiewicz², \\ Dawid Sigorski', Waldemar J. Placek'
}

\author{
'Department of Dermatology, Sexually Transmitted Diseases and Clinical Immunology, University of Warmia and Mazury, Olsztyn, \\ Poland \\ ${ }^{2}$ Department of Ophthalmology, Regional Specialist Hospital, Olsztyn, Poland \\ ${ }^{3}$ Clinical Department of Oncology and Immunooncology, MSWiA Independent Public Healthcare Centre with Warmińsko-Mazurskie \\ Oncology Centre, Olsztyn, Poland
}

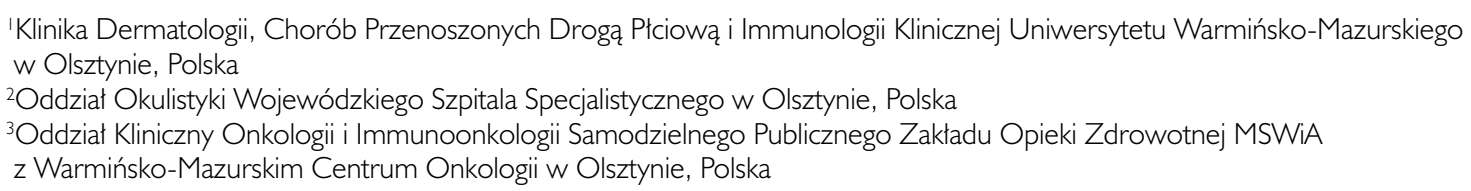

\section{CORRESPONDING AUTHOR/ ADRES DO KORESPONDENCJI: dr n. med. Agnieszka Markiewicz Klinika Dermatologii, Chorób Przenoszonych Drogą Płciową i Immunologii Klinicznej Uniwersytet Warmińsko-Mazurski ul. Wojska Polskiego 30 10-229 Olsztyn, Polska tel.: +48602658879 e-mail: agaen@wp.pl}

\begin{abstract}
Mantle cell lymphoma is a rare neoplastic disease of the lymphatic system derived from mature B lymphocytes. It very commonly affects extranodal sites including the bone marrow, gastrointestinal tract and Waldeyer's ring, but skin involvement is seen extremely rarely. The disease often has a recurrent and aggressive course. The diagnosis is usually established late, at an advanced stage of the disease. We present the case of a patient with skin lesions developing as the first manifestation of a haematological disease. After the appearance of symptoms the patient had several medical consultations before the final diagnosis was made at a dermatology outpatient clinic. Only few cases of cutaneous manifestations of mantle cell lymphoma have been described.
\end{abstract}

\section{STRESZCZENIE}

Chłoniak z komórek płaszcza jest rzadko występującą chorobą nowotworową układu chłonnego wywodzącą się z dojrzałych limfocytów B. Często zajmuje lokalizacje pozawęzłowe, zazwyczaj szpik kostny, układ pokarmowy, pierścień Waldeyera, ale wyjątkowo rzadko skórę. Choroba zwykle charakteryzuje się nawrotowym, agresywnym przebiegiem. Najczęściej rozpoznawana jest późno, w zaawansowanym stadium. Przedstawiamy przypadek pacjenta, u którego zmiany skórne były pierwszym objawem choroby hematologicznej. Pacjent $\mathrm{z}$ powodu objawów odbył kilka konsultacji lekarskich, zanim postawiono ostateczną diagnozę podczas wizyty w poradni dermatologicznej. Dotychczas opisano niewiele przypadków skórnej manifestacji chłoniaka z komórek płaszcza.

Key words: mantle cell lymphoma, skin manifestations of lymphomas, lymphomas.

Słowa kluczowe: chłoniak z komórek płaszcza, skórne manifestacje chłoniaków, chłoniaki. 


\section{INTRODUCTION}

Mantle cell lymphoma (MCL) is a rare cancer of the lymphatic system, derived from mature B lymphocytes. The hallmark of MCL is $t(11 ; 14)(q 13 ; q 32)$ translocation which leads to overexpression of cyclin-D1. The disease is often characterized by a recurrent aggressive course. The diagnosis is most commonly made late, when the disease has already reached an advanced stage. Mantle cell lymphoma frequently occurs in extranodal sites including the bone marrow, gastrointestinal tract and Waldeyer's ring, but skin involvement is seen extremely rarely [1].

Although there are few reports on skin manifestations of mantle cell lymphoma, the disease can be divided into primary cutaneous lymphoma (according to the criteria of the European Organization for Research and Treatment of Cancer (EORTC)) and extracutaneous lymphoma secondarily involving the skin.

\section{Classification}

Mantle cell lymphoma was formally recognized as a distinct subtype of non-Hodgkin lymphomas in 1992, and in 1994 it was incorporated into the Revised European-American Classification of Lymphoid Neoplasms. It is also included as a separate disease entity in the World Health Organization (WHO) classification $[2,3]$. However, MCL is not listed as a separate entity in the World Health Organization - European Organization for Research and Treatment of Cancer (WHO-EORTC) classification for primary cutaneous lymphomas.

\section{Skin manifestations}

The available literature includes few case reports of mantle cell lymphoma with cutaneous involvement. One of the papers described a disease with features of primary cutaneous lymphoma in which the lesion manifested as a solitary nodule and, following treatment, did not evolve into systemic disease [4]. There is also a report of a patient who presented with extensive maculopapular lesions located on the upper extremities, progressing into bullae which necrotized.

According to the literature, the most commonly affected skin areas include the trunk (60\%), face (30\%), arms $(20 \%)$, followed by the hips, legs and scalp. One of few available case studies found that skin lesions were nodular in $34 \%$, macular or maculopapular also in $34 \%$, tumoural or infiltrated plaques in $21 \%$ and subcutaneous nodules in $11 \%$ of cases $[5,6]$.

\section{CASE REPORT}

A 55-year-old patient presented to a general practitioner with oedematous lesions and erythema with local bruising in the auricular regions. Infiltrative lesions,

\section{WPROWADZENIE}

Chłoniak z komórek płaszcza (mantle cell lymphoma MCL) jest rzadko występującą chorobą nowotworową układu chłonnego wywodzącą się z dojrzałych limfocytów B. Istotą jej powstania jest translokacja $t(11 ; 14)$ (q13;q32), która prowadzi do nadekspresji cykliny D1. Choroba często ma nawrotowy, agresywny przebieg. Zwykle rozpoznanie ustala się późno, już w zaawansowanym stadium. Chłoniak często zajmuje lokalizacje pozawęzłowe, zazwyczaj szpik kostny, układ pokarmowy, pierścień Waldeyera, ale wyjątkowo rzadko skórę [1].

Chociaż istnieje niewiele doniesień dotyczących skórnych manifestacji chłoniaka z komórek płaszcza, można podzielić je na: chłoniaka pierwotnie skórnego (zgodnie z kryteriami European Organization for Research and Treatment of Cancer - EORTC) oraz chłoniaka zajmującego skórę wtórnie do choroby o innej lokalizacji.

\section{Klasyfikacja}

Chłoniak z komórek płaszcza został zidentyfikowany jako oddzielny podtyp chłoniaków nieziarniczych w 1992 r., a w 1994 r. włączono go do zrewidowanej europejsko-amerykańskiej klasyfikacji nowotworów układu chłonnego. Znajduje się również jako odrębna jednostka chorobowa w klasyfikacji Światowej Organizacji Zdrowia [2, 3]. Chłoniak ten nie został uwzględniony jako osobna jednostka w Klasyfikacji pierwotnych chłoniaków skóry wg World Health Organization - European Organization for Research and Treatment of Cancer (WHO-EORTC).

\section{Manifestacje skórne}

W piśmiennictwie dostępnych jest niewiele opisów przypadków chłoniaka z komórek płaszcza przebiegającego ze zmianami skórnymi. Znane są doniesienia o chorobie mającej formę chłoniaka pierwotnie skórnego, gdzie zmiana miała postać pojedynczego guzka i po jej leczeniu nie rozwinęła się choroba układowa [4]. Opisano również pacjenta, który zgłosił się z powodu rozległych zmian plamisto-grudkowych zlokalizowanych na kończynach górnych. Na ich podłożu powstały później pęcherze, które uległy martwicy.

Według piśmiennictwa najczęstsze lokalizacje skórne to: tułów $(60 \%)$, twarz (30\%), ramiona $(20 \%)$, następnie okolice biodrowe, kończyny dolne i skóra owłosiona głowy. W jednej z niewielu analiz przypadków stwierdzono, że zmiany mają charakter guzkowaty w 34\%, plamisty lub plamisto-grudkowy w $34 \%$, charakter guzowaty lub postać nacieczonych ognisk w $21 \%$ oraz guzów podskórnych w 11\% [5, 6].

\section{OPIS PRZYPADKU}

Pacjent 55-letni zgłosił się do lekarza rodzinnego z powodu obrzęku i rumienia z ogniskowymi zasi- 
though much less pronounced, were also present in the areas of the supraorbital ridges. The patient stated that the lesions occurred approximately a month previously, without any accompanying general symptoms. The man was referred for an outpatient consultation with a laryngologist who found no abnormalities on examination and prescribed treatment with amoxicillin + clavulanic acid, loratadine and prednisone. Laboratory tests were not ordered at the time.

The consulting laryngologist referred the patient to the Dermatology Department with suspected polychondritis.

On admission to the Department, infiltrated erythematous lesions were noted on the auricles, cheeks, nose and in the regions of the supraorbital ridges. Physical examination revealed no significant abnormalities. The patient reported night sweats and pruritus as well as body weight loss of approximately $7 \mathrm{~kg}$ over the past 2 months. Laboratory tests demonstrated marked leukocytosis $\left(85.46 \times 10^{3} / \mu \mathrm{l}\right)$ with lymphocytic predominance $\left(75.62 \times 10^{3} / \mu \mathrm{l} ; 88 \%\right)$, erythrocyte sedimentation rate (ESR) $21 \mathrm{~mm}$, C-reactive protein (CRP) $0.7 \mathrm{mg} / 1$, lactate dehydrogenase (LDH) $406 \mathrm{U} / 1$. In microscopic differential cell count lymphocytes accounted for $96 \%$, divided lymphocytes for $3 \%$ and monocytes for $1 \%$. Also, anisocytosis and Gumprecht's shadows were noted. In addition, antinuclear antibodies were assayed, with a positive titre at $1: 1280$ (granular fluorescence pattern, no further specification was done). A biopsy was performed to collect a connective tissue sample from an auricle for histopathological examination. Histopathological findings were consistent with mantle cell lymphoma (CD45+, CD20+, CD79+, CD5+, Bcl2+, CD23+/-, Ki67+ in 15\% of lymphocytes, CD138-, CD3-, CD4-, CD8-, CD56-, CD7-, CD43-, CD30-, CD10-, mum1-, Bcl6-) (figs. 1, 2).

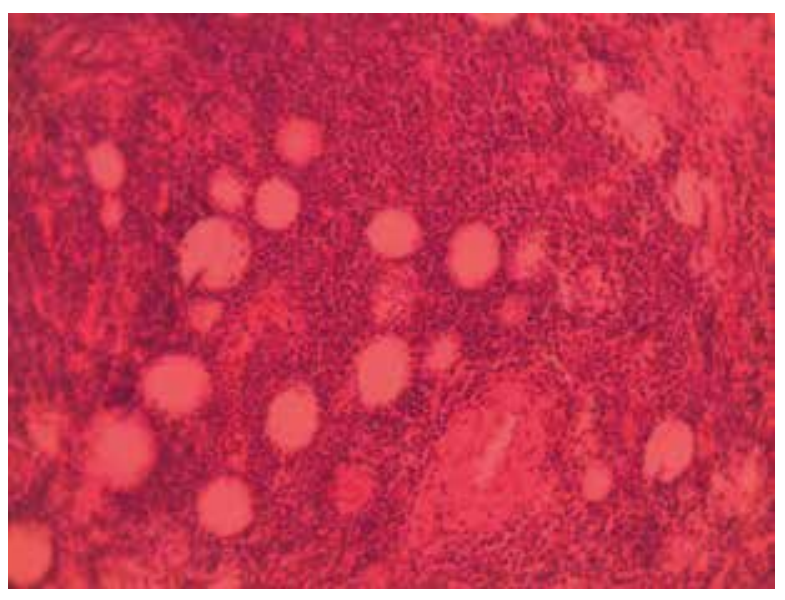

Figure I. Histopathological examination. Infiltrate of small monomorphic lymphocytes

Rycina I. Badanie histopatologiczne. Naciek z małych monomorficznych limfocytów nieniami w okolicy małżowin usznych. Zmiany naciekowe, choć znacznie mniej nasilone, były obecne także w okolicach łuków brwiowych. Chory podawał, że zmiany pojawiły się około miesiąca wcześniej i nie towarzyszyły im objawy ogólne. Został skonsultowany ambulatoryjnie przez laryngologa, który nie stwierdził nieprawidłowości w badaniu i zalecił leczenie amoksycyliną z kwasem klawulanowym, loratadyną i prednizonem. Chory nie miał wówczas wykonanych badań laboratoryjnych.

Pacjent został skierowany z poradni laryngologicznej do oddziału dermatologii z podejrzeniem zapalenia wielochrząstkowego.

Przy przyjęciu do Kliniki obserwowano zmiany naciekowo-rumieniowe zlokalizowane na małżowinach usznych, policzkach, nosie i w okolicach łuków brwiowych. W badaniu przedmiotowym nie stwierdzono istotnych nieprawidłowości. W wywiadzie chory podawał poty nocne i świąd skóry oraz utratę masy ciała - ok. $7 \mathrm{~kg} \mathrm{w}$ czasie ostatnich 2 miesięcy. W badaniach laboratoryjnych stwierdzono znaczną leukocytozę $\left(85,46 \times 10^{3} / \mu \mathrm{l}\right)$ z istotną przewagą limfocytów $\left(75,62 \times 10^{3} /\right.$ $\mu \mathrm{l} ; 88, \%)$, OB $21 \mathrm{~mm}$, białko C-reaktywne (CRP) $0,7 \mathrm{mg} / 1$, dehydrogenaza mleczanowa (LDH) $406 \mathrm{U} / 1$. W rozmazie mikroskopowym limfocyty stanowiły $96 \%$, podzielone $3 \%$, monocyty $1 \%$ oraz opisywano anizocytozę i cienie Gumprechta. Oznaczono również przeciwciała przeciwjądrowe, miano 1 : 1280 (ziarnisty typ świecenia, nie wykonano specyfikacji). Pobrano wycinek tkanki łącznej małżowiny usznej do badania histopatologicznego, w której rozpoznano chłoniaka z komórek płaszcza (CD 45+, CD20+, CD79+, CD5+, Bcl2+, CD23+/-, Ki67+ w 15\% limfocytów, CD138-, CD3-, CD4-, CD8-, CD56-, CD7-, CD43-, CD30-, CD10-, mum1-, Bcl6-) (ryc. 1, 2).

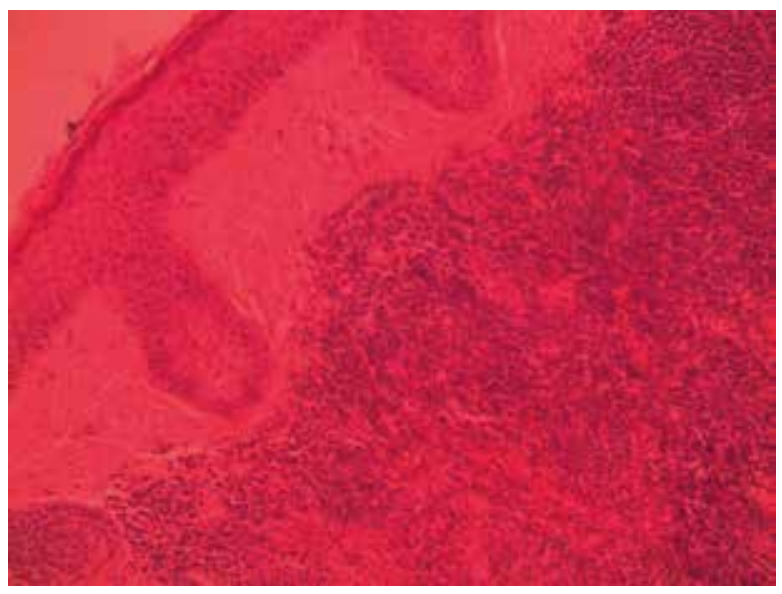

Figure 2. Histopathological examination. Subcutaneous infiltrate Rycina 2. Badanie histopatologiczne. Naciek w tkance podskórnej 
The patient was urgently referred to the Department of Haematology, where the diagnosis of mantle cell lymphoma was confirmed. Histopathological analysis of the right axillary lymph node found mantle cell lymphoma - common variant, with nodular structure (LCA+, CD20+, CD5+, cyclin-D1+, BCL2+, Ki67+ in approx. 25\% of cells, CD23- (+ in follicular dendritic cells) CD3-, CD10-, Bcl6-, MUM1-. Histopathological examination of a bone marrow sample obtained by trephine biopsy revealed infiltrates of mantle cell lymphoma (CD20+, cyclin-D1+, CD5+, $\mathrm{BCl} 2+, \mathrm{CD} 3-)$ which accounted for approximately $80 \%$ of all bone marrow tissue.

A computed tomography (CT) scan was performed, showing multiple enlarged lymph nodes in the mediastinum, pulmonary hila, area of tracheal bifurcation, coeliac trunk and lesser curvature of the stomach. Ann Arbor stage III was diagnosed. Chemotherapy was immediately started, initially with two courses of the R-CHOP regimen (rituximab, cyclophosphamide, doxorubicin, vincristine, prednisolone). After the treatment and between the cycles the patient developed severe infectious complications combined with exacerbation of heart failure and pulmonary oedema. The next regimen administered to the patient was R-DHAP (dexamethasone, cytarabine, cisplatin, rituximab). After the therapy the patient developed symptoms of acute kidney injury, which necessitated a change of treatment modality. Chemotherapy was continued with the R-COP regimen (rituximab, cyclophosphamide, vincristine, prednisone). Following the treatment the patient was again hospitalized at the Department of Haematology with severe pneumonia. During the hospitalization, the patient died.

\section{DISCUSSION}

We present the case of a patient diagnosed with mantle cell lymphoma with bone marrow involvement. It is a nosological entity which always requires differential diagnostics with chronic myeloid leukaemia carrying a much more favourable prognosis. The possibility of secondary bone marrow involvement by lymphoma and transformation of leukaemia to lymphoma (Richter's syndrome) should be considered.

The diagnostic process is particularly challenging in atypical variants of leukaemia. Both diseases are characterized by CD5+ and CD19+ coexpression. The basis for the diagnosis of chronic lymphocytic leukaemia is typically the Matutes score based on 5 parameters: CD5, CD22 (later replaced by CD79b), CD23, FMC7 and sIg. Based on this classification, the atypical variant of leukaemia is identified, which is most commonly mistaken for mantle cell lymphoma. In order to differentiate between both diseases, it is helpful to assess cyclin-D1, SOX11 or translocation
Pacjenta $\mathrm{w}$ trybie pilnym skierowano do oddziału hematologii. Tam potwierdzono rozpoznanie chłoniaka z komórek płaszcza. W badaniu histopatologicznym węzła chłonnego pachowego strony prawej stwierdzono chłoniaka z komórek płaszcza, postać zwykłą o budowie guzkowej (LCA+, CD20+, CD5+, cyklina D1+, BCL2+, Ki67+ w ok. 25\% komórek, CD23- (+ w komórkach dendrytycznych ośrodków rozmnażania) CD3-, CD10-, Bcl6-, MUM1-. W badaniu histopatologicznym wycinka z trepanobiopsji szpiku kostnego wykazano nacieki chłoniaka z komórek płaszcza (CD20+, cyklina D1+, CD5+, BCl2+, CD3-), które stanowiły ok. 80\% całego utkania szpiku.

W badaniu tomografii komputerowej (TK) klatki piersiowej stwierdzono liczne powiększone węzły chłonne w śródpiersiu, we wnękach płucnych, w okolicy rozwidlenia tchawicy, a także $\mathrm{w}$ okolicy pnia trzewnego i krzywizny mniejszej żołądka. Rozpoznano stopień zaawansowania III wg Ann Arbor. Natychmiast włączono chemioterapię. Najpierw dwukrotnie wg schematu R-CHOP (rytuksymab, cyklofosfamid, doksorubicyna, winkrystyna, prednizolon). Po tym leczeniu, a także między cyklami u pacjenta wystąpiły ciężkie powikłania infekcyjne połączone z zaostrzeniem niewydolności krążeniowo-oddechowej z obrzękiem płuc. Następnie zastosowano schemat R-DHAP (deksametazon, cytarabina, cisplatyna, rytuksymab). Po tej terapii u pacjenta pojawiły się objawy ostrego uszkodzenia nerek, co spowodowało, że konieczna była modyfikacja leczenia, które kontynuowano wg schematu R-COP (rytuksymab, cyklofosfamid, winkrystyna, prednizon). Po terapii pacjent ponownie był hospitalizowany $\mathrm{w}$ oddziale hematologii z powodu zapalenia płuc o ciężkim przebiegu. Podczas tej hospitalizacji chory zmarł.

\section{OMÓWIENIE}

Opisano przypadek pacjenta, u którego rozpoznano chłoniaka z komórek płaszcza z zajęciem szpiku kostnego. Jest to jednostka chorobowa, która zawsze wymaga diagnostyki różnicowej z przewlekłą białaczką szpikową, w przypadku której rokowanie jest dużo korzystniejsze. Należy brać pod uwagę możliwość wtórnego zajęcia szpiku kostnego przez chłoniaka oraz transformacji białaczki do chłoniaka (zespół Richtera).

Diagnostyka jest szczególnie trudna w przypadku atypowych postaci białaczki. Obie choroby charakteryzuje koekspresja CD5+ i CD19+. Do rozpoznania przewlekłej białaczki limfocytowej powszechnie stosuje się skalę Matutesa, w której bierze się pod uwagę 5 parametrów: CD5, CD22 (później zastąpioną CD79b), CD23, FMC7 oraz sIg. Na podstawie tej klasyfikacji rozróżnia się postać atypową, która najczęściej jest błędnie rozpoznawana jako chłoniak 
$t(11 ; 14)$. It seems, however, that better methods for the differentiation of the diseases are necessary. One of such methods may be based on CD200 and CD43 assessment [7].

Especially challenging is the differentiation with mantle cell lymphoma associated with lymphocytosis. Some authors identify a "leukaemic" variant of this type of lymphoma [8].

The literature includes relatively few case studies of skin manifestation of mantle cell lymphoma. In 2013, a case report was published of a 56-year-old male patient admitted to a haematology department with progressive fatigue, hepatosplenomegaly and enlarged lymph nodes on the neck and in the axillary and inguinal regions. Physical examination revealed maculopapular rash located on both upper extremities. Four days after its appearance tense bullae formed within affected areas, and resolved leaving behind shallow erosions. Skin biopsy failed to reveal any lymphocytic infiltrate. Notable laboratory findings included leukocytosis $(18,000 / \mu \mathrm{l})$, anaemia and thrombocytopaenia. Lymph node and bone marrow examinations confirmed the diagnosis of mantle cell lymphoma (CD20+, CD43+, cyclin-D1+, bcl-2+, bcl-6+). The patient received R-CHOP chemotherapy. After 5 cycles a complete remission of skin lesions was achieved, together with regression of lymphadenopathy and organomegaly, and normalization of laboratory findings [9].

One case report also describes a patient with disseminated petechial maculopapular eruption as a skin manifestation of mantle cell lymphoma. A 50-year-old male patient was hospitalized at a dermatology department. In addition to cutaneous lesions, physical examination revealed lymphadenopathy and abnormalities in laboratory findings (leukocytosis: 26,900/ $\mu$ l). Skin biopsy demonstrated lymphocytic infiltrates. Immunophenotyping showed the following profile: CD20+, CD5+, cyclin-D1+. The patient was treated by intensive chemotherapy followed by allogeneic stem cell transplant [10].

In 2015 Polish authors published a case report describing a 63-year-old female patient hospitalized at a dermatology department because of infiltrated erythematous lesions on the skin of the face and ears, accompanied by hyperpigmentation on the skin of the upper trunk. Other abnormalities demonstrated by physical examination included peripheral lymphadenopathy, progressive dyspnoea and dry mouth. Laboratory tests showed leukocytosis $(24,000 /$ $\mu \mathrm{l})$ with lymphocytosis $(75 \%)$ and anaemia ( $\mathrm{Hgb}$ $7.7 \mathrm{~g} / \mathrm{dl}$ ). Histopathological examination of an ear skin sample revealed a massive lymphocytic infiltrate of the skin and subcutaneous tissue. Lymph node and bone marrow examinations confirmed the presence of lymphocytic infiltrates. Immunohistochemical ex- z komórek płaszcza. Pomocne w rozróżnieniu tych jednostek jest oznaczenie cykliny D1, SOX11 lub translokacji $\mathrm{t}(11 ; 14)$. Nadal jednak wydaje się, że niezbędne są lepsze metody różnicowania tych chorób. Jedną z nich może się okazać oznaczanie CD200 i CD43 [7].

Wyjątkowo trudne jest różnicowanie chłoniaka z komórek płaszcza, z którym współwystępuje limfocytoza. Niektórzy autorzy wyróżniają „leukemiczną" postać tego chłoniaka [8].

W piśmiennictwie stosunkowo rzadko spotyka się opisy przypadków skórnej manifestacji chłoniaka z komórek płaszcza. W 2013 r. opisano przypadek 56-letniego pacjenta hospitalizowanego w oddziale hematologii z powodu narastającego uczucia zmęczenia, hepatosplenomegalii oraz powiększonych węzłów chłonnych karkowych, pachowych i pachwinowych. W badaniu przedmiotowym stwierdzono osutkę grudkowo-plamistą zlokalizowaną obustronnie na kończynach górnych, w obrębie której po ok. 4 dniach od wystąpienia pojawiły się dobrze napięte pęcherze, ustępujące z pozostawieniem płytkich nadżerek. W wycinku skóry nie wykazano obecności nacieku limfocytarnego. W badaniach laboratoryjnych uwagę zwróciły leukocytoza (18 tys./ $\mu \mathrm{l})$, niedokrwistość oraz małopłytkowość. Badania węzła chłonnego oraz szpiku kostnego potwierdziły rozpoznanie chłoniaka z komórek płaszcza (CD20+, CD43+, cyklina D1+, bcl-2+, bcl-6+). W leczeniu zastosowano schemat R-CHOP. Po 5 cyklach uzyskano remisję w zakresie zmian skórnych oraz limfadenopatii, organomegalii i wyników badań laboratoryjnych [9].

Opisano także rozsianą, grudkowo-plamistą, krwotoczną osutkę jako skórną manifestację chłoniaka z komórek płaszcza. U 50-letniego pacjenta hospitalizowanego w klinice dermatologicznej w badaniu przedmiotowym poza zmianami skórnymi stwierdzono także limfadenopatię oraz nieprawidłowe wyniki badań laboratoryjnych (leukocytoza 26,9 tys./ $\mu \mathrm{l})$. W wycinku skóry opisano nacieki limfocytarne. Immunofenotypizacja wykazała profil: CD20+, CD5+, cyklina D1+. W leczeniu zastosowano intensywną chemioterapię $\mathrm{z}$ następczym allogenicznym przeszczepieniem komórek macierzystych [10].

Polscy autorzy opublikowali w 2015 r. opis przypadku 63-letniej pacjentki hospitalizowanej w klinice dermatologii z powodu zmian rumieniowo-naciekowych skóry twarzy i uszu z towarzyszącymi przebarwieniami na skórze górnej części tułowia. W badaniu przedmiotowym stwierdzono ponadto obwodową limfadenopatię, narastającą duszność i suchość błony śluzowej jamy ustnej. W badaniach laboratoryjnych wykazano leukocytozę (24 tys./ $\mu \mathrm{l}$ ) z limfocytozą (75\%) oraz niedokrwistość (Hgb 7,7 g/dl). W badaniu histopatologicznym skóry uszu uwidoczniono masywny naciek limfocytarny skóry i tkanki pod- 
amination of the skin, lymph node and bone marrow revealed the following cells: CD20+, CD19+, CD5+, cyclin-D1+. Computed tomography scan showed a tumorous lesion in the larynx and enlarged lymph nodes in the mediastinum, abdominal cavity and pelvis minor. Stage IV D/B mantle cell lymphoma was diagnosed. CHOP chemotherapy was administered. After 5 rounds a partial remission of skin lesions and relief of dyspnoea were achieved. Seven months later, however, the disease recurred. DHAP (dexamethasone, cytarabine, cisplatin) chemotherapy was administered, but it proved ineffective and the patient died several weeks later (approximately a year after diagnosis) [11].

Although there are many literature reports on gastrointestinal symptoms accompanying non-Hodgkin lymphomas, relatively little attention is given to their possible location in the rectal area. One case report describes a 63-year-old man admitted to a surgery department with a gradually progressive tumour-like mass with a smooth surface, non-tender on palpation, located in the perirectal region. The lesion was accompanied by lymph node enlargement in the left inguinal region. No significant abnormalities were identified on anoscopy or in laboratory tests. The lesion was excised in its entirety together with the inguinal lymph nodes. Based on histopathological findings, mantle cell lymphoma was diagnosed. The patient died from progressive cardiorespiratory failure 43 days after the surgery [12].

Autoimmune diseases are known to potentially coexist with solid tumours, but also with lymphoproliferative diseases. There is a reported case of systemic sclerosis coexisting with mantle cell lymphoma in a 76-year-old female patient admitted to a haematology department with peripheral lymphadenopathy. Physical examination found thickening of the skin on the forearms and histopathological findings confirmed the diagnosis of scleroderma. A medical interview revealed that the patient had experienced Raynaud's phenomenon and dysphagia for 2 years preceding the onset of skin lesions. ANA Hep-2 test was positive at a titre of $1: 1280$ (ACA > 1: 640, Scl 70 negative). Computed tomography examination of the chest found no evidence of fibrosis, and echocardiography revealed moderately enlarged left cardiac ventricle and pulmonary hypertension. Colonoscopy revealed multiple colonic polyps which were analyzed histopathologically and found to be consistent with mantle cell lymphoma (CD20+, blc2+, CD43+, CD79a+, cyclin-D1+). Bone marrow biopsy demonstrated monoclonal B cell proliferation. Axillary lymph node examination confirmed the diagnosis (Ki67-50\%), stage III B mantle cell lymphoma was diagnosed. Treatment comprised R-CHOP chemotherapy (with complete response achieved after 6 cycles), skórnej, w badaniu węzła chłonnego i szpiku kostnego potwierdzono nacieki limfocytarne. $W$ badaniu immunohistochemicznym skóry, węzła chłonnego oraz szpiku stwierdzono obecność komórek CD20+, CD19+, CD5+, cykliny D1+. W TK wykazano m.in. zmianę guzowatą krtani oraz powiększone węzły chłonne śródpiersia, jamy brzusznej i miednicy mniejszej. Rozpoznano stadium IV D/B chłoniaka z komórek płaszcza. W leczeniu zastosowano schemat CHOP. Po 5 wlewach uzyskano częściowe ustąpienie zmian skórnych oraz ustąpienie duszności, jednak po 7 miesiącach stwierdzono wznowę choroby. Zastosowany wówczas schemat DHAP (deksametazon, cytarabina, cisplatyna) okazał się nieskuteczny i pacjentka zmarła po kilku tygodniach (ok. 1 roku od rozpoznania) [11].

Mimo często opisywanych w piśmiennictwie objawów żołądkowo-jelitowych towarzyszących chłoniakom nieziarniczym, stosunkowo rzadko zwraca się uwagę na ich możliwą lokalizację w okolicy odbytnicy. Opisano przypadek 63-letniego pacjenta hospitalizowanego w oddziale chirurgicznym z powodu stopniowo narastającej, niebolesnej palpacyjnie masy guzowatej w okolicy odbytnicy, o gładkiej powierzchni. Zmianie towarzyszyło powiększenie lewostronnych węzłów pachwinowych. W badaniach laboratoryjnych oraz anoskopii nie stwierdzono istotnych nieprawidłowości. Zmianę usunięto w całości wraz z węzłami chłonnymi pachwinowymi. W badaniu histopatologicznym rozpoznano chłoniaka z komórek płaszcza. Pacjent zmarł w 43. dobie po operacji z powodu narastających objawów niewydolności krążeniowo-oddechowej [12].

Choroby autoimmunologiczne mogą współwystępować nie tylko z guzami litymi, lecz także chorobami limfoproliferacyjnymi. Przedstawiono przypadek współwystępowania twardziny układowej z chłoniakiem z komórek płaszcza u 76-letniej pacjentki hospitalizowanej w oddziale hematologii z powodu limfadenopatii obwodowej. W badaniu przedmiotowym stwierdzono pogrubienie skóry przedramion, a badanie histopatologiczne sugerowało rozpoznanie twardziny. W badaniu podmiotowym potwierdzono występowanie objawu Raynauda oraz dysfagii 2 lata przed pojawieniem się zmian skórnych. Badanie ANA na komórkach Hep-2 wykazało obecność przeciwciał w mianie $1: 1280$ (ACA > $1: 640$, Scl 70 ujemne). W TK klatki piersiowej nie zaobserwowano cech włóknienia, a w echokardiografii wykazano mierne powiększenie lewej komory serca oraz nadciśnienie płucne. W kolonoskopii stwierdzono liczne polipy okrężnicy, które $\mathrm{w}$ badaniu histopatologicznym zostały określone jako chłoniak z komórek płaszcza (CD 20+, blc2+, CD43+, CD79a+, cyklina D1+). W biopsji szpiku kostnego wykazano rozrost monoklonalny limfocytów B. Badanie węzła chłonnego pachowego potwierdziło dia- 
pentoxifylline and nifedipine. Three-year follow-up revealed no recurrence of lymphoma or exacerbation of systemic sclerosis symptoms [13].

In 2015, a retrospective analysis was published including 1,321 histopathological lymph node examinations performed in patients diagnosed with mantle cell lymphoma based on medical registers in Kiel (Lymph Node Registry Kiel). Skin involvement was noted in just $1 \%$ (14 patients) of analyzed subjects, with $58 \%$ of skin lesions located on the lower extremities. Immunophenotyping of the examined tissues revealed a profile consistent with B-cell lymphoma, leg-type. The differentiation between both diseases was only possible on the basis of cyclin-D1 and translocation $t(11 ; 14)$ analysis. On that basis, the authors recommended routine tests to detect cyclin-D1 expression in cases of suspected mantle cell lymphoma [14].

Another study, analyzing extranodal locations of MCL, found skin involvement in $12 \%$ of cases $(9 / 78)$, which was linked in a statistically significant manner to the predominance of blasts on cytological examination. There was no statistically significant correlation between extranodal location and survival [15].

\section{CONCLUSIONS}

Mantle cell lymphoma is a very rare disorder in the practice of dermatology specialists. Similarly to other lymphomas, the manifestations of Mantle cell lymphoma may be highly varied. The case reported above shows that seemingly trivial symptoms may result in the diagnosis of conditions carrying a serious prognosis. Furthermore, it demonstrates that at least basic laboratory tests should be performed in cases involving diagnostic difficulties.

\section{CONFLICT OF INTEREST}

The authors declare no conflict of interest. gnozę (Ki67- 50\%), rozpoznano stadium III B chłoniaka z komórek płaszcza. W leczeniu zastosowano schemat R-CHOP (po 6 cyklach uzyskano pełną odpowiedź), pentoksyfilinę oraz nifedypinę. W 3-letniej obserwacji nie stwierdzono wznowy chłoniaka oraz nasilenia objawów twardziny układowej [13].

W 2015 r. opublikowano retrospektywną analizę 1321 badań histopatologicznych węzłów chłonnych pacjentów z rozpoznanym chłoniakiem z komórek płaszcza, zarejestrowanych w Kilonii (Lymph Node Registry Kiel). Wśród nich jedynie u 1\% (14 chorych) obserwowano zajęcie skóry, w 58\% zmiany skórne były zlokalizowane na kończynach dolnych. Immunofenotypowanie badanych tkanek wykazało profil charakterystyczny dla chłoniaka B-komórkowego, leg-type. Jedynie ekspresja cykliny D1 oraz translokacji t $(11 ; 14)$ umożliwiła zróżnicowanie tych dwóch chorób. Na tej podstawie zalecono rutynowe poszukiwanie ekspresji cykliny D1 przy podejrzeniu chłoniaka z komórek płaszcza [14].

$\mathrm{W}$ innej analizie obejmującej pozawęzłowe lokalizacje chłoniaka z komórek płaszcza stwierdzono zajęcie skóry w 12\% przypadków (9/78), co było statystycznie istotnie związane z przewagą blastów w cytologii. Nie wykazano statystycznie istotnej korelacji między pozawęzłową lokalizacją i przeżyciem [15].

\section{WNIOSKI}

Chłoniak z komórek płaszcza jest chorobą bardzo rzadko spotykaną w praktyce lekarza dermatologa. Objawy choroby, podobnie jak innych chłoniaków, mogą mieć bardzo różnorodny obraz kliniczny. Opisany przypadek jest przykładem rozpoznania o poważnym rokowaniu, z pozornie niegroźnymi objawami klinicznymi. Ponadto potwierdza fakt konieczności wykonywania co najmniej badań podstawowych w przypadkach trudności diagnostycznych.

\section{KONFLIKT INTERESÓW}

Autorzy deklarują brak konfliktu interesów.

\section{References \\ Piśmiennictwo}

1. Szymczyk M., Walewski J.: Chłoniak z komórek płaszcza - współczesne poglądy na diagnostykę i leczenie. Hematologia 2010, 1, 330-341.

2. Swerdlow S.H., Campo E., Harris N.L., Jaffe E.S., Pileri S.A., Stein H., et al.: WHO classification of tumours of haematopoietic and lymphoid tissues. IARC Press, Lyon 2008.

3. Harris N.L., Jaffe E.S., Stein H., Banks P.M., Chan J.K., Cleary M.L., et al.:. A revised European-American classification of lymphoid neoplasms: a proposal from the International Lymphoma Study Group. Blood 1994, 84, 1361-1392.

4. Sen F., Medeiros L.J., Lu D., Jones D., Lai R., Katz R., et al.: Mantle cell lymphoma involving skin: cutaneous lesions may be the first manifestation of disease and tumors often have blastoid cytologic features. Am J Surg Pathol 2002, 26, 1312-1318.

5. Motegi S., Okada E., Nagai Y., Tamura A., Ishikawa O.: Skin manifestation of mantle cell lymphoma. Eur J Dermatol 2006, $16,435-438$. 
6. Canpolat F., Taş E., Albayrak Sönmez A., Oktay M., Eskioğlu F., Alper M.: Cutaneous presentation of mantle cell lymphoma. Acta Derm Venereol 2010, 90, 548-550.

7. Falay M., Afacan Öztürk B., Güneş K., Kalpakçı Y., Dağdaş S., Ceran F., et al.: The role of CD200 and CD43 expression in differential diagnosis between chronic lymphocytic leukemia and mantle cell lymphoma. Turk J Haematol 2017, doi: 10.4274/ tjh.2017.0085.

8. Schlette E., Lai R, Onciu M., Doherty D., Bueso-Ramos C., Medeiros L.J.: Leukemic mantle cell lymphoma: clinical and pathologic spectrum of twenty-three cases. Mod Pathol 2001, 14, 1133-1140.

9. Singh A.K., Dixit G., Sharma S., Kumar S., Yadav R., Agrawal N., et al.: Skin manifestation associated with mantle cell lymphoma: a case report. Mediterr J Hematol Infect Dis 2013, 5, e2013020.

10. Jawed S.I., Hollmann T.J., Moskowitz C.H., Desman G., Querfeld C.: Disseminated mantle cell lymphoma presenting as a petechial maculopapular eruption. JAMA Dermatol 2014, 150, 94-96.

11. Kalińska-Bienias A., Ziarkiewicz-Wróblewska B., Kowalewski C., Woźniak K.: Mantle cell lymphoma with skin involvement. Postep Dermatol Alergol 2015, 32, 229-234.

12. Gulcu B., Ozer A., Nazlioglu H.O., Ozturk E., Yilmazlar T.: Perianal mantle cell lymphoma mimicking an external thrombosed hemorrhoid: a case report. J Med Case Rep 2014, 8, 40.

13. Marto G., Aguiar R., Barcelos A.: Mantle cell lymphoma and systemic sclerosis. Acta Reumatol Port 2014, 39 , 82-86.

14. Wehkamp U., Pott C., Unterhalt M., Koch K., Weichenthal M., Klapper W., et al.: Skin involvement of mantle cell lymphoma may mimic primary cutaneous diffuse large B-cell lymphoma, leg type. Am J Surg Pathol 2015, 39, 1093-101.

15. Baheti A.D., Tirumani S.H., Sewatkar R., Sachin S.S., Shinagare A.B., Ramaiya N.H.: MDCT of extranodal mantle cell lymphoma: a single institute experience. Abdom Imaging 2015, 40, 1693-1699.

Received: 27.07 .2017

Accepted: 21.09.2017

Otrzymano: 27.07.2017 r.

Zaakceptowano: 21.09.2017 r.

How to cite this article

Markiewicz A., Zdanowska N., Owczarczyk-Saczonek A.B., Markiewicz M.M., Sigorski D., Placek W..J.: Skin manifestation of mantle cell lymphoma - case report and literature review. Dermatol Rev/Przegl Dermatol 2017, 104, 655-662.

DOI: https://doi.org/10.5114/dr.2017.71837. 